\title{
Domestic Violence In India (Socio-Legal Aspects) With Special Reference To Protection Officer Under Dvp, Act - How Far They Are Successful In Providing Solace To Th E Victims?
}

\author{
Ms. Nargis Yeasmeen \\ Ll.B, Llm (West Bengal National University of Juridical Sciences)
}

\section{Introduction:}

"Violence against women is a manifestation of historically unequal power relations between men and women, which have led to domination over and discrimination against women by men and to the prevention of the full advancement of women."

The United Nations Declaration on the Elimination of Violence against Women, General Assembly Resolution, December 1993.

Women are often in great danger in the place where they should be the safest i.e. within their families. For many 'home' is that place where they have to face a regime of terror and violence in the hands of somebody close to them - somebody they should be able to trust. ${ }^{2}$ It is that place that imperils lives and breeds some of the most drastic and heinous forms of violence perpetrated against women and girls. Those victimized suffer physically and psychologically. With different processes of socialization that men and women undergo, men take up stereotyped gender roles of domination and control, whereas women take up that of submission, dependence and respect for the authority. ${ }^{3}$ A female child grows up with a constant sense of being weak and in need of protection, whether physical, social or economic. This helplessness has led her to be exploitable at almost every stage of life. ${ }^{4}$ They are even unable to make their own decisions, enjoy their basic fundamental rights or even voice their own opinion for fear of further repercussions. ${ }^{5}$ Their human rights are denied, even equality, security, self-worth and dignity are at stake and their lives are stolen from them by the ever-ending threat of violence. This violence against women has increased manifold, though this torture on them is not new, it is an old phenomenon from the time when the social organization and family life came into existence - be it rape, gang-rape, torture for dowry, illegal confinement, kidnapping, abduction, molestation, honour - killing, physical assault, acid attack, sexual harassment or female infanticide. In addition, they also have to bear the brunt of pernicious practices like child- marriage, sati, prostitution, forced marriages, wife-beating, stalking, bride- burning, passing lewd comments, black-mailing, sex-determination, sexual abuse of the girl child and medical neglect are wide spread both in rural and urban areas. Women in India are subjected to domestic, physical, emotional and mental violence. The safety of women, who constitute of almost half of the country's population, still remains a far cry. ${ }^{6}$ They do not feel safe while coming out of their houses, walking on roads, travelling in public transport, undergoing medical treatment in hospitals, studying in educational institutions and also living within the four walls of their houses. In this male dominated society, women are exploited both at home and outside. They are always treated as second class citizens.

Now, before understanding what the position of women is in this current time, we should go back to the pre-independence time to compare their position as of now. According to scholars, women in ancient India enjoyed equal status in all respect of life. They were given proper education in the early Vedic period, were married at a matured age and were also free to select their own husbands. ${ }^{7}$ But the status of women declined with

\footnotetext{
${ }^{1}$ The United Nations Declaration on the Elimination of Violence against Women, General Assembly Resolution, December 1993.

${ }^{2}$ Innocent Digest, No.6, June 2000, "Domestic Violence against Women and Girls." Unicef, United Nations Children's Fund Innocenti Research Centre Florence, Italy

${ }^{3}$ Sheela Saravanan, "Violence against Women in India." Institute of Social Studies Trust (ISST) March 2000

${ }^{4}$ Lawyers' Collective (Women's Rights Initiatives); Staying Alive: $1^{\text {st }}$ Monitoring and Evaluation Report, 2007 on the Protection of Women from Domestic Violence Act, 2005, New Delhi 2007

${ }^{5}$ Supra Note 2

${ }^{6}$ Marisa Silvestri \& Chris Crowther - Dowet, “Gender and Crime.” Sage Publications Ptd.

${ }^{7}$ R.C. Majumdar and A.D. Pusaker, "History and Culture of the Indian People." Vol - 1, Pg - 394 The Vedic Age, Bombay Bharatiya Vidya Bhawan, 1955
} 
the Islamic invasion of Babur and the Mughal Empire and it further deteriorated during the medieval period when child marriages and a ban on widow remarriages became part of social life in some communities in India. ${ }^{8}$ Polygamy became to be practiced among Hindu Kshatriya rulers. During the British Raj, many reformers such as Raja Ram Mohan Roy, Ishwar Chandra Vidyasagar and many others fought for the betterment of women. Women also played an integral role in Indian Independence struggle. Thus it can be understood the women played a vital part during the pre-independence time. ${ }^{9}$

The new millennium has brought with it a greater push towards acknowledging the incidence of violence against women and an international consensus has developed on the need to deal with the issue. The Convention on the Elimination of all forms of Discrimination against Women ${ }^{10}$ adopted by the UN General Assembly some 20 years ago and the Platform for Action adopted at the Fourth International Conference on Women in Beijing in 1995 all reflect this consensus. Further the Protection of Women from Domestic Violence Act, 2005, the Sexual Offences Act, 2003, builds some policies nationally and locally over the past decade, aiming to reduce the incidence of sexual and domestic violence and improve the treatment of victims by the criminal justice system. ${ }^{11}$ The Domestic Violence Act which came into force on 26.10 .2006 is in tune with the above mentioned International Conventions. The Pre-conception and Pre-Natal Diagnostic Techniques (Prohibition of Sex Selection) Act, 1994 was also introduced to prevent the misuse of diagnostic techniques resulting in sex selection abortion. But progress has been slow due to entrenched attitudes.

The researcher has primarily used the doctrinal method of research. Different Legal Text books on the Domestic Violence Act are the primary sources. While relevant text, articles, case laws, as well as internet are the secondary sources.

For the purpose of this project, the researcher has divided the entire project into five chapters. They are as follows:

Before delving deep into the concept of "domestic violence", it is pertinent here to explain certain terms for proper understanding of this article. They are discussed under Chapter I.

\section{Definition of 'Domestic Violence', 'Domestic Relationship', 'Aggrieved Person'}

1) Definition of "Domestic Violence"

There is no universally accepted definition of violence against women. Some human rights activists prefer a broad-based definition that includes 'structural violence' such as poverty and unequal access to health and education. ${ }^{12}$ Others have argued for a more limited definition in order not to lose the actual descriptive power of the term. ${ }^{13}$ The term 'domestic violence' includes violence by an intimate person or by any other family members, wherever this violence takes place and in whatever form.

The United Nations Declaration on the Elimination of Violence against Women (1993) defines domestic violence against women as, "an act of gender-based violence that results in, or is likely to result in physical, sexual or psychological harm or suffering to women, including threats of such acts, coercion or arbitrary deprivation of liberty, whether occurring in public or public life." 14

Section 3 of the Protection of Women from Domestic Violence act, 2005 has clearly stated the definition of "domestic violence". It includes that any act, omission, commission or conduct of the respondent shall constitute domestic violence in cases of ${ }^{15}$ :

\footnotetext{
${ }^{8}$ Ibid

${ }^{9}$ Supra note 7

${ }^{10}$ The United Nations Convention on Elimination of all forms of Discrimination Against Women defines discrimination against women as, “........any distinction, exclusion or restriction made on the basis of sex which has the effect or purpose of impairing or nullifying the recognition, enjoyment or exercise by women, irrespective of their marital status, on a basis of equality of men and women, of human rights and fundamental freedoms in the political, economic, social, cultural, civil or any other field."

${ }^{11}$ Supra note 2

${ }^{12}$ Heise LL Pitanguy J. and Germaine A. (1994), “Violence against Women: The Hidden Health Burden.” Discussion Paper No. 225, pg. 46, Washington DC, The World Bank.

${ }^{13}$ Heise LL Pitanguy J. and Germaine A. (1994), “Violence against Women: The Hidden Health Burden”. Discussion Paper No. 225, pg. 46, Washington DC, the World Bank.

${ }^{14}$ General Assembly Resolution 48/104 of $20^{\text {th }}$ December, 1993.

${ }^{15}$ Section 3 of the Protection of Women from Domestic Violence Act, 2005
} 
(a) harms or injures or endangers the health, safety, life, limb or well-being, whether mental or physical, of the aggrieved person or tends to do so and includes causing physical abuse, sexual abuse, verbal and emotional abuse and economic abuse; or

(b) harasses, harms, injures or endangers the aggrieved person with a view to coerce her or any other person related to her to meet any unlawful demand for any dowry or other property or valuable security; or

(c) has the effect of threatening the aggrieved person or any person related to her by any conduct mentioned in clause (a) or clause (b); or

(d) otherwise injures or causes harm, whether physical or mental, to the aggrieved person.

The Fourth Conference of Women, 1995, has defined violence against women as "a physical act of aggression of one individual or group against another or others. Violence against women is any act of gender-based violence which results in physical, sexual or arbitrary deprivation of liberty in public or private life and violation of human rights of women in situation of armed conflicts. ${ }^{16}$

Thus, the above are few definitions of Domestic Violence which gives a detail insight about the concept and perception of the above mentioned term i.e. domestic violence.

\section{2) Definition of "Domestic relationship"}

Under Section 2(f) of the Act, "domestic relationship" means a relationship between two persons who live or have, at any point of time, lived together in a shared household, when they are related by consanguinity, marriage or through a relationship in nature of marriage, adoption or are family members living in a joint family. ${ }^{17}$ The scope of this provision is very wide. In a famous case of Nandan Singh Manral vs. State ${ }^{18}$, the notice was served on the brother-in-law. But it was held that the husband of the married sister, who lived far away from the family of the husband, cannot be said to have lived in shared household with the aggrieved person as no domestic relationship existed. Hence, the notice served on the brother-in-law was quashed.

In contrast, the scope of Section $498 \mathrm{~A}$ of the Indian Penal Code ${ }^{19}$ was essentially included to punish the husband and the in-laws of the bride for the act of cruelty. In the case of domestic violence also, the perpetrator is the male against a women. Now, if the husband or the relatives of the husband commits an act of domestic violence through his male relatives or through his female relatives, it is deemed that there was an act of domestic violence for which the relatives and the husband will be held responsible. Here the order of the Magistrate will be binding on the parties, and non- compliance with the orders of the Magistrate amounts to an offence which is punishable under Section 31 of Protection of Women from Domestic Violence Act, $2005 .{ }^{20}$

Thus the above definition though, its scope is very large, mentions and points out the true ambit of domestic violence.

\section{3) Definition of "Aggrieved Person"}

According to Section 2(a) of the Protection of Women from Domestic Violence Act, 2005, aggrieved person means any woman who is, or has been, in a domestic relationship with the respondent and who alleges to have been subjected to any act of domestic violence. ${ }^{21}$

\section{Causes of Domestic Violence}

There are no single causes/factors that contribute to the violence perpetrated against women. For the purpose of this article, the researcher has divided the types of causes of violence against women into five headings. They are cultural, economic, legal and political. Let me discuss them one by one under the following heads:

\footnotetext{
${ }^{16}$ Conference on Women, Beijing 1995, Country Report

${ }^{17}$ Section 2(f) of the Protection of Women from Domestic Violence Act, 2005

${ }^{18}$ 2011(2)RCR (Criminal) 271, Delhi

${ }^{19}$ Section 498A - Husband or relative of a husband of a women subjecting her to cruelty -

Whoever, being the husband or the relative of the husband of women, subjects such women to cruelty shall be punished with imprisonment for a term which may extend to three years and shall also be liable to fine.

Explanation - For the purposes of this section, "Cruelty" means -

(a) Any willful conduct which is of such nature as is likely to drive the women to commit suicide or to cause grave injury or danger to life, limb or health (whether mental or physical) of the women; or

(b) Harassment of the women where such harassment is with a view to coercing her or any person related to her to meet any unlawful demand for any property or valuable security or is on account of failure by her or any person related to her to meet such demand.

${ }^{20}$ Section 31 of the said act, "Penalty for Breach of Protection Order by Respondent."

${ }^{21}$ Section 2(a) of the Protection of Women from Domestic Violence Act, 2005
} 


\section{Cultural:}

Acceptability of violence as a means to resolve conflict is the major reason of violence against women. Victims generally feel that it is better to suffer in silence than to be separated from their loved ones. They keep hoping for improvement but their wait turns into a nightmare without any remedy. Religious and historical tradition in the past have sanctioned the chastising and beating of women. ${ }^{22}$ The male members control family wealth, and as such it places decision- making authority in male hands, leading to its dominance. Traditional norms in those societies also allow the killing of 'errant' daughters and wives suspected of defiling the honour of the family. Even, experiences during childhood, such as witnessing domestic violence and experiencing physical and sexual abuse have been identified as factors that put children at risk. Excessive consumption of alcohol has been noted as a factor in provoking aggressive and violent male violence towards women. ${ }^{23}$

\section{Economic:}

Another important factor that contributes to the violence against women is the economic and financial dependence of women on men. This is generally true when the male person is unemployed and feels his power undermined in the household. The threat and fear of violence keeps women from seeking employment or compels them to accept low-paid exploitative labour. ${ }^{24}$ And on the other hand, without economic independence, women have no power to escape from an abusive relationship. ${ }^{25}$

\section{Legal:}

Improper and inadequate laws and legal status of women is the primary cause for domestic violence. In India, laws relating to divorce, child custody, maintenance and inheritance are always in favour of men, ignoring women's rights. This has further led to violence on the women. The law enforcement agencies are also less sensitive towards women and their problems and always tend to guard the male counter-part. In many places it is seen that the perpetrators who commit violence are less prosecuted and punished leniently. This finally tends to break the will power of women and they submit themselves before the male society. The last nail which is driven into the coffin of all women is that they are less educated than their male counter-part.

\section{Political:}

The isolation of women from communities and less participation in the field of politics also contribute to more of violence on women. As their interactions with strangers or outer people are less, so they become victims of violence. They fear to raise their timid voices, least they fall prey to more violence than before.

Thus, the above are the causes that contribute to domestic violence on women. But now-a-days the scenario is changing with the passage of time. Women are more financial independent than before; they pursue their higher studies and even raise their strong voice against their male-counter-part. Now domestic violence is taken up seriously.

\section{Types Of Violence:}

After recognizing the causes that lead to violence against women, it is essential to know the different types of violence. Though there cannot be any specific type of violence, violence is such which tends to lower the self-esteem of an individual. Still the researcher has identified some types of domestic violence against women. They are as follows: ${ }^{26}$

- Violence which is money oriented;

- Violence which is the result of stressful family situation;

- Violence which seeks power over the weak;

- Violence which is the result of the perpetrators pathology;

- Violence which aims at pleasure seeking;

- Violence which is victim precipitated.

But one thing is to be noted here is that, the primary difference between domestic violence and any other violence is, the former is committed by an intimate partner or family members of that partner. These types of violence are generally done by those men who suffer from depression, inferiority complex, self low-esteem,

\footnotetext{
${ }^{22}$ Asmila Basu, "Harmful Practices against Women in India: An Explanation of Selected Legislative Response."

${ }^{23}$ Ibid

${ }^{24}$ Asmila Basu, "Harmful Practices against Women in India: An Explanation of Selected Legislative response."

${ }^{25}$ Schuler S.R, Hashemi S.M, et al.."Men’s Violence against Women in Rural Bangladesh.” Vol 43 No.12 pg 1729-1742, 1996

${ }^{26}$ Dr. S. Gokilavan, Dr. S.G Jelestin, "Marriage, Dowry Practice and Divorce.” Pg. 252 Regal Publication, New Delhi (2008) 
personality disorders, and psychopaths, have suspicious and dominant nature, victim of violence in childhood and frequent users of alcohol.

The table below shows the types of domestic violence in different stages of life of a woman.

(Source: "Violence Against Women" WHO, FRH/WHD/97.9)

\begin{tabular}{|cl|l|}
\hline \multicolumn{2}{|l|}{ Phase } & Type of violence \\
\hline 1. & Pre-Birth & Sex-selective abortion; Effects of battering during pregnancy on birth outcome. \\
\hline 2. & Infancy & Female infanticide; Physical, sexual and psychological abuse. \\
\hline 3. & Girlhood & $\begin{array}{l}\text { Child marriage; Female genital mutilation; Physical, sexual and Psychological abuse; Incest; Child } \\
\text { Prostitution and Pornography. }\end{array}$ \\
\hline $4 . \quad \begin{array}{l}\text { Adolescence and } \\
\text { Adulthood }\end{array}$ & $\begin{array}{l}\text { Dating and courtship violence (Ex. Acid throwing and rape), Economically coerced sex (Ex. School } \\
\text { girls having sex with "sugar Daddies" in return of school fees; sexual abuse n the workplace; Rape; } \\
\text { Sexual Harassment; Incest; Trafficking in women; forced prostitution and pornography; Marital Rape; } \\
\text { Dowry Abuse and murders; Psychological abuse; Forced pregnancy; Abuse of Women with Disabilities. }\end{array}$ \\
\hline $5 . \quad$ Elderly & $\begin{array}{l}\text { Forced "suicide" or homicide of widows for economic reasons; Physical, Sexual and Psychological } \\
\text { Abuse. }\end{array}$ \\
\hline
\end{tabular}

Thus, the above table shows that violence against women is a cycle/chain of abuse that manifests itself in numerous forms throughout her life.

\section{Legislative Check-Up On Domestic Violence In India}

Before discussing the legislative check-up, it is advisable to know first as to who may file the complaint. Complaint may be filed on behalf of the aggrieved women or any of the members of the household against any other member or members of the household. The husband of the aggrieved women can file a complaint on behalf of his wife against other members of the family who have committed the acts of domestic violence on the aggrieved women. Likewise the father-in-law can also file the complaint on behalf of the aggrieved women. It is to be noted here that only male would not be the respondents. But the complaint must be filed by any aggrieved women.

It is also to be noted here that, the cause of action for instituting a case under this act must be in the occurrence of domestic violence in present or which is continuing. But if the violence is done by any outsiders, then the proceedings will not be under the Domestic Violence Act, instead it will be triable under any other criminal law as ordered by the Magistrate.

The problems of violence on women are arising at a high note day by day. Be it illiterate women or educated, they have to face these violence at some point of their life. To match with this social transformation and growing needs of the society, the Parliament in 2005 enacted the Protection of Women from Domestic Violence Act, 2005. Before the passing of this act, there were certain laws like Sections 304B ${ }^{27}$ and 498A (has already been discussed in Foot Note No. 13) of the Indian Penal Code, Sections $112^{28}$ and $113 \mathrm{~B}^{29}$ of the Indian Evidence Act, 1872, the Dowry Prohibition Act, the Hindu Marriage Act, 1955, Section $125^{30}$ of the Code of Criminal Procedure, the Muslim Women (Protection of Rights on Divorce) Act, 1986, the Immoral Traffic (Prevention) Act, 1956 and many others. But none of the above mentioned acts dealt entirely on the problems of domestic violence. So the need was felt to materialize something/law which would only look after the problem of domestic violence, hence this act was passed. But no amendments were made since its birth and women are still tortured physically and mentally and even killed or driven to suicide by their husbands and in-laws. The

\footnotetext{
${ }^{27}$ Section 304B of IPC states Dowry Death - (1) Where the death of a woman is caused by any burns or bodily injury or occurs otherwise than under normal circumstances within seven years of her marriage and it is shown that soon before her death she was subjected to cruelty or harassment by her husband or any relative of her husband for, or in connection with, any demand for dowry, such death shall be called "dowry death', and such husband or relative shall be deemed to have caused her death.

Explanation - For the purposes of this sub-section, "dowry "shall have the same meaning as in Section 2 of the Dowry Prohibition Act, 1961 (28 of 1961)

(2) Whoever commits dowry death shall be punished with imprisonment for a term which shall not be less than seven years but which may extend to imprisonment for life.
}

${ }^{28}$ Section 112 of Indian Evidence Act, 1872 states, "Birth during marriage, conclusive proof of legitimacy". It states that the fact that any person was born during the continuance of a valid marriage between his mother and any man, or within two hundred and eighty days after its dissolution, the other remaining unmarried, shall be conclusive proof that he is the legitimate son of that man, unless it can be shown that the parties to the marriage has no access to each other at any time when he could have been begotten.

${ }^{29}$ Section $113 \mathrm{~B}$ of the Indian Evidence Act, 1872 states, "Presumption as to dowry death." It states that when the question is whether a person has committed the dowry death of a woman and it is shown that soon before her death such woman has been subjected by such person to cruelty or harassment for, or in connection with, any demand for dowry, the Court shall presume that such person has caused the dowry death.

Explanation - For the purpose of this section, "dowry death" shall have the same meaning as in section 304B of the Indian Penal Code.

${ }^{30}$ Section 125 of Cr.P.C states, "Order for Maintenance of Wives, Children, and Parents." 
Dowry Prohibition Act, 1961 was amended in 1984, 1985 and 1986. Even Section 498A was introduced in the Indian Penal Code, but nothing is so far done other than just enacting the law. It is to be mentioned here that no provision for protection of the complainant is provided under the Domestic Violence Act. A woman who has complained of harassment goes back to those very people against whom she has complained. What security can be possibly given to such victims who continue to act on her complain?

One cannot predict the future of Protection of Women from Domestic Violence Act, 2005; its current workings provide some ideas on rationalizing drafting and implementation processes. The limitation of this law with regards to its use in preventing harmful practices is that it recognizes civil wrongs whereas the gravity of harmful practices requires a response in criminal law. Secondly, it applies only to practices that are perpetrated by those in a domestic relationship, whereas, other entities might be involved in perpetrating harmful practices.

Thus, it can be clearly understood from the above discussion that, strong voice should be raised to bring in more clarity and transparency in the act. Different amendments should be made to make the law more effective and fruitful for the oppressed victims. Comprehensive laws on key issues, such as statutory equality code, a criminal law on violence against women and a comprehensive legislation to the regulation of medical practice. Each of the above mentioned laws should be co-related both in terms of the mode in which implementation is envisaged and in terms of defining its ambit. Efforts should also be made to educate women in adopting the methods which is necessary for the implementation of the law.

\section{Appointment Of The Protection Officers - How Far They Are Successful In Providing Solace To The Victims?}

A Protection Officer is an outreach officer of the Court (not yet appointed in all the states) who can help a women in making complaints, filing an application before the Magistrate for orders, helping her in getting support, like medical aid, counseling etc. and also make sure that the orders passed by the Court are enforced (Section 9 of the Act and Rule 8 and 10). She/he is someone who is appointed within jurisdiction of each local Magistrate, by the Government under Section 8 of the Protection of Women from Domestic Violence Act, 2005 and the duties of such officers are laid down in Section $\mathbf{5}$ of the said act. It is to be noted that, the appointment of the Protection Officers have been done by vesting additional responsibilities on existing government officials and they seem to function better. The reason behind their effectiveness is that they work under the direct supervision of the criminal courts, and hence are compelled to take action on receiving complaints of domestic violence.

When an event of domestic violence comes to the notice of these Protection Officers, their first duty is to contact the aggrieved women and inform her about the existence of this particular act and the remedy that she might benefit out of it. She should also be explained that she can apply to the Magistrate for protection order, order for monetary relief, order relating to custody of children and orders for providing medical relief, if required. She must also be informed that, if she desires she can even seek for free legal aid from the Legal Services Authority. If she is further interested she may even file a complaint under Section 498A of the Indian Penal Code, 1860, provided the facts of the case come within the purview of the said section. Thus, it can be seen that the Protection Officers perform a dual role of facilitating an aggrieved women's access to the court and support services, in addition to assisting the court in discharging its functions. It should be noted here that penalties can also be imposed on these Protection Officers for dereliction of duties as imposed on them.

We can conclude by saying that these Protection Officers deliver their duties and help the aggrieved women in getting relief speedily. They are successful in their duties and their work as assigned to them.

\section{Conclusion:}

The above article focuses on domestic violence as one of the most prevalent yet relatively hidden and ignored forms of violence against women. Domestic violence is a health, legal, economic, educational, development and above all, a human rights issue. It may also take the form of depriving her of the necessities of her life and her children. Selling away any properties of the women or of the respondent to deprive women of her rights and privileges also come within the scope of domestic violence. ${ }^{31}$ Thus, it can be seen that violence against women is present in every country cutting across the boundaries of cultures, class, education, income, ethnicity and age. To sum up briefly, there are ample evidences to suggest that at a policy and institutional level criminal justice agencies have gone a way ahead in taking the domestic violence seriously. This act functions as machinery for those aggrieved women restricting violence against them, living in the shared household. It is not a punishing legislation, but a protective measure, and for more effective protection of the rights of the women guaranteed under the Indian Constitution and for matters connected therewith or incidental thereto. Therefore,

\footnotetext{
${ }^{31}$ N.K Archarya, Commentary on the protection of Women from Domestic Violence Act, 2005, $4^{\text {th }}$ Edition pg. 23, Asia Law House, Hyderabad (2010)
} 
the act created an officer called Protection Officer (already discussed above). Besides this, two other institutions are created, namely, Shelter Home and an institution called Medical Facility.

In substance, anything done or threatening to cripple a women physically and mentally amounts to domestic violence. ${ }^{32}$ Confining or detaining the spouse against one's will or damaging property is also considered as acts of violence. Domestic Violence is a serious hindrance to marriage harmony and should not be tolerated by any women at any cost. Effort should be made to ensure that women get the respect and honour in their homes as well as outside. There is an urgent need for the society to change; mindset of the male dominated society should be more and broader. Women should not be treated as commodities; rather they should be treated as asset of the families. There is a sharp contrast in the traditional Indian society, we worship all Goddess like Kali, Durga, Saraswati, Laksmi, Mansa and many others with great pomp, respect and glamour, but women in our house are treated no less than animals. "Marriage" is a sacred bond/relationship which is made in heaven, and the foundation of marriage is tolerance, adjustment, love, faithfulness, loyalty and respect for one another. Petty misunderstandings and trifling differences should not be aggravated so that the relationship which was made in heaven becomes destroyed.

To conclude, I would like to add a simple but equally important thing, that is, women should not misuse the special laws (Section 498A of the IPC) which are enacted only for their betterment and to protect them from oppression.

\section{Books:}

\section{Bibliography/References:}

[1]. P.K Das, "Universal Handbook on Publication on Protection of Women from Domestic Violence Act and Rule". Pg. 3, $2^{\text {nd }}$ Edition, Universal law Publishing House, New Delhi (2007)

[2]. K.D Kaur, “Text Book on Indian Penal Code.” Pg. 514, $4^{\text {th }}$ Edition, Universal Publishing Co., New Delhi (2010)

[3]. Dr. S. Gokilavan, Dr. S.G Jelestin, "Marriage, Dowry Practice and Divorce”. Pg. 21, Regal Publication, New Delhi (2008)

[4]. N.K. Archarya, "Commentary of Women from Domestic Violence Act, 2005". Pg. 23, 4th Edition, Asia Law House, Hyderabad (2010)

Articles:

[5]. Thomas B Jeyaseelan, "Women Rights and Law.” Pg. 2, Indian Social Institute, New Delhi (2002)

[6]. Asmila Basu, "Harmful Practices against Women in India: An Explanation of Selected Legislative Responses."

[7]. Sheela Saravanan, "Violence against Women in India."Institute of Social Studies Trust (ISST) March 2000

[8]. Cybele Cochran, "The Fletcher School Online Journal on Southwest Asia and Islamic Civilization." (2009)

[9]. Cybele Cochran, "Women and the Law in Islamic Societies: Legal Reforms to Domestic Violence in Saudi Arabia and Morocco."

[10]. Heise LL Pitanguy,Germaine A, “Violence against Women :The Hidden Health, Burden." Discussion paper no. 225, pg. 46, Washington DC, The World Bank

[11]. Dr. S. Gokilavan, Dr. SG Jelestin, “Marriage. Dowry, Practice and Divorce.” Pg. 252, Regal Publication, New Delhi (2008)

[12]. Schuler S.R, Hashemi SM, “Men’s Violence against Women in Rural Bangladesh.” Vol. 43, Pg. 1729-1742, 1996

Cases:

[13]. Nandan Singh Manral vs. State 2011 (2) RCR (Criminal) 271 Delhi

Statutes:

[14]. Protection of Women from Domestic Violence Act, 2005

[15]. Dowry Prohibition Act, 1961

[16]. Relevant provisions of the Indian Evidence Act, 1872

[17]. Relevant provisions of Code of Criminal Procedure, including procedure to obtain maintenance

[18]. Relevant provisions of Indian Penal Code, 1860, including provisions on dowry-deaths, cruelty within marriage, rape, molestation, etc.

[19]. Commission of Sati (Prevention) Act, 1987 